\section{Mer til ettertanke enn til trøst}

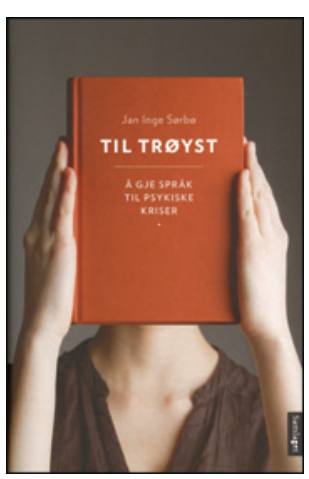

Jan Inge Sørbø

Til trøyst

Å gje språk til psykiske kriser. 240 s.

Oslo: Samlaget, 2013. Pris NOK 329

ISBN 978-82-521-8310-8

Til trøyst er en lovende tittel. I vaskeseddelen på baksiden heter det at medisinen ikke har et godt nok språk for de følelsene og erfaringene som folk får ved psykiske sykdommer og plager, men at litteraturen kan være en stor og sjenerøs kilde til slik innsikt og forståelse. Forfatteren, litteraturprofessor Jan Inge Sørbø, gir en rekke eksempler på forfattere som har skrevet om psykiske kriser av ulik type, ofte med utgangspunkt i deres egne opplevelser.

Det er åpenbart riktig at medisinens tredjepersonsspråk er annerledes enn en beskrivelse av en personlig opplevelse skrevet i førsteperson. I kapitlet om Beate Grimsruds roman En dåre fri blir journalspråket kontrastert mot romanfigurens, Elis, egen opplevelse: «Pas har klart hallusinatoriske opplevelser. Pas er motorisk urolig under samtalen .... .» Og så kontrasten, Elis egen stemme: «Jeg vil hjem. Jeg vil ut. Jeg vil ut av Erik ... Jeg vil hjem til Eli, som bestemmer.» Noen og hver av oss kan kjenne oss igjen $i$ at pasientens perspektiv lett blir borte i journalspråkets kjølige prosa. Det å møte pasientens egen stemme kan derfor være nyttig og verdifullt.

Undertittelen er «Å gje språk til psykiske kriser». Det finnes studier som ved hjelp av bildedannende teknikker viser at det å sette navn på følelser kan være assosiert med redusert aktivering i sentre $\mathrm{i}$ hjernen som er selve motoren i de negative følelsene, og med økt aktivering i frontale strukturer som fremmer emosjonell regulering. Det å sette ord på sin angst eller fortvilelse kan altså være et gode i seg selv, det kan være til trøst.

I kapitlet Angstens ansikt er det flere eksempler på hvordan lyrikeren og barnebokforfatteren Oskar Stein Bjørlykke har satt ord på angsten, ord som er sterkt personlige, enkle og nakne, som i diktet Pusten og angsten: «Det vanskelege livet pustar. Døden gjer det/ ikkje. Ein gong du stod der og heiv så rart / etter pusten, forstod eg med eitt kva du var / redd for.» Dette og andre eksempler er klokt kommentert av Sørbø.

Andre ganger blir det mer en populærfaglig drøfting av tekstene og forfatterne enn et nært møte med ordene som uttrykk for personlige kriser.

For en leser som er interessert i litteratur, er dette en meget leseverdig gjennomgang av hvordan en rekke forfattere har behandlet temaer knyttet til psykiske kriser og lidelser. Men noen ganger kunne jeg ønsket litt mer søkelys på selve tekstene, på ordene som potensielt er til trøst, og kanskje litt mindre på den litteraturhistoriske konteksten.

\section{Arnstein Finset}

Professor, Institutt for medisinske basalfag Universitetet i Oslo

\section{Tankevekkende om psykisk helsearbeid}

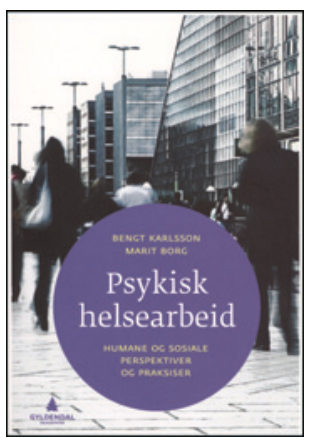

Bengt Karlsson, Marit Borg

\section{Psykisk helsearbeid}

Humane og sosiale perspektiver og praksiser.

213 s. Oslo: Gyldendal Akademisk, 2013.

Pris NOK 345

ISBN 978-82-05-42015-1

Forfatternes formål er «å løfte frem det humane og det sosiale perspektivet $\mathrm{i}$ arbeidet med psykisk helse». Jeg forstår dem slik at de først og fremst henvender seg til fagpersoner innen psykisk helsearbeid og til brukere av tjenestene.

De tre delene, Humane og sosiale grunnlagsforståelser, Det sosiale perspektivet og Kontekster og praksiser, er tankevekkende på flere plan. Først og fremst fordi de inneholder mye klokt og viktig. Forfatterne understreker behovet for det relasjonelle perspektivet og at brukere og pårørende møtes med respekt og inviteres til aktiv medvirkning. De legger vekt på sosiale og samfunnsmessige forståelser og forklaringer, på dialog med brukerne og på at personer med psykisk uhelse er eksperter på egne liv og kan ta ansvar for å mestre dem.

Det er et klart og tydelig budskap om å erstatte monolog og ekspertvelde med dialog og jevnbyrdighet. Samtidig har boken en polemiserende stil som står i tankevekkende kontrast til budskapet om dialog. Forfatterne må ha vært oppmerksomme på denne kontrasten, for de skriver i innledningen: «Vår ambisjon er å løfte frem og tidvis insistere på vår forståelse - ikke fordi det er det eneste sanne og rette, men for å understreke nødvendigheten av det humane og sosiale perspektivet. Dette innebærer at teksten tidvis kan være lite dialogisk, $i$ den forstand at den blir mer argumenterende i sitt perspektiv enn drøftende og overveiende. Det kan fremstå som en utfordring ved boken, særlig gitt dens dialogiske grunntone.»

Etter min mening er grunntonen mer polemisk enn dialogisk. Forfatterne skriver for eksempel: «Den hjelpen som er blitt gitt i psykisk helsevern har i for lang tid vært utviklet på hjelperens eller ekspertens premisser. Dette har ført til inhumane praksiser som sosial ekskludering, stigmatisering, overgrep og undertrykkelse.» Dette blir for meg en svært enkel problemforståelse. Psykisk helsevern har hatt gjentatte forsøk på reformer i retning av mer dialog og mindre ekspertvelde. Et eksempel er det terapeutiske samfunn med slagordet «Culture of inquiry», undringskulturen. Jeg deler forfatternes bekymring for at vi i dag ser altfor lite til en slik kultur, og at krav til produksjon, pasientgjennomstrømming og tidseffektivitet truer betingelsene for samtalen i terapeutisk arbeid.

Forfatterne tar opp mange viktige spørsmål som burde gi grunnlag for en bred dialog som inkluderer alle aktører i psykisk helsearbeid. Men det vil kreve et genuint ønske om dialog på bred front.

Svein Friis

Overlege, Klinikk psykisk helse og avhengighet Oslo universitetssykehus 